\title{
Androgen profiles during pubertal Leydig cell development in mice
}

\author{
Xiufeng Wu, Ramamani Arumugam ${ }^{1}$, Ningning Zhang and Mary M Lee \\ Pediatric Endocrine Division, Departments of Pediatrics and Cell Biology, University of Massachusetts \\ Medical School, 55 Lake Avenue North, Worcester, Massachusetts 01655, USA and ${ }^{7}$ Pediatric Endocrine \\ Division, Duke University Medical Center, Durham, North Carolina 27710, USA
}

Correspondence should be addressed to M M Lee; Email: mary.lee@umassmemorial.org

\begin{abstract}
Postnatal Leydig cell (LC) development in mice has been assumed empirically to resemble that of rats, which have characteristic hormonal profiles at well-defined maturational stages. To characterize the changes in LC function and gene expression in mice, we examined reproductive hormone expression from birth to 180 days, and quantified in vivo and in vitro production of androgens during sexual maturation. Although the overall plasma androgen and LH profiles from birth through puberty were comparable to that of rats, the timing of developmental changes in androgen production and steroidogenic capacity of isolated LCs differed. In mice, onset of androgen biosynthetic capacity, distinguished by an acute rise in androstenedione and testosterone production and an increased expression of the steroidogenic enzymes, cytochrome P450 cholesterol side-chain cleavage enzyme and 17 $\alpha$-hydroxylase, occurred at day 24 (d24) rather than at $\mathrm{d} 21$ as reported in rats. Moreover, in contrast to persistently high testosterone production by pubertal and adult rat LCs, testosterone production was maximal at $\mathrm{d45}$ in mice, and then declined in mature LCs. The murine LCs also respond more robustly to LH stimulation, with a greater increment in LH-stimulated testosterone production. Collectively, these data suggest that the mouse LC lineage has a delayed onset, and that it has an accelerated pace of maturation compared with the rat LC lineage. Across comparable maturational stages, LCs exhibit species-specific developmental changes in enzyme expression and capacity for androgen production. Our results demonstrate distinct differences in LC differentiation between mice and rats, and provide informative data for assessing reproductive phenotypes of recombinant mouse models.

Reproduction (2010) 140 113-121
\end{abstract}

\section{Introduction}

During rodent testis development, Leydig cells (LCs) arise as two discrete but overlapping populations, fetal and adult type. During embryogenesis, androgens produced by the fetal LCs are essential for masculinization. At birth, the fetal LC population declines dramatically in number by undergoing apoptotic cell death or dedifferentiation (Gondos et al. 1977, Kuopio et al. 1989), although residual fetal LCs have been identified in the pubertal testis (Kerr \& Knell 1988). Adult-type LCs, which arise from mesenchymal precursor cells, start to differentiate at postnatal day $10(\mathrm{~d} 10)-\mathrm{d} 14$ in rats and at d7-d10 in mice (Mendis-Handagama et al. 1987, Hardy et al. 1989, Vergouwen et al. 1991, Nef et al. 2000), and then gradually mature to adult LCs. Terminal differentiation of postnatal LCs is needed at puberty and in adults for the production of testosterone, which is essential for secondary sexual maturation, male mating behavior, and fertility.

In rats, the development of differentiating adult-type LCs has traditionally been divided into three distinct maturational stages: progenitor, immature, and adult (Shan et al. 1993, Benton et al. 1995). PLCs are present from $\mathrm{d} 14$ to $\mathrm{d} 28$, and then differentiate into ILCs from d28 to d35 and fully mature to ALCs by d56 (Shan et al. 1993, Benton et al. 1995). Each sequential stage exhibits characteristic cellular structural features and androgen profiles. Rat PLCs proliferate actively, and start to express androgen biosynthetic enzymes, cytochrome P450 cholesterol side-chain cleavage enzyme (P450scc), and $17 \alpha$-hydroxylase (P450c17 $\alpha$ ). Owing to the low expression of steroidogenic enzymes that are present abundantly in more mature LCs, i.e. type III $17 \beta$-hydroxysteroid

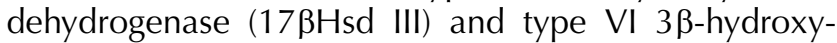
steroid dehydrogenase $(3 \beta \mathrm{Hsd} \mathrm{VI})$, the predominant androgens produced at this stage are androstenedione and androsterone (Shan et al. 1993, Benton et al. 1995, Ge \& Hardy 1998). By d28, PLCs differentiate into ILCs in rats, which express high levels of both androgen biosynthetic and metabolizing enzymes, making androstanediol the most abundant androgen. By d56, the ILCs terminally differentiate into ALCs that still express type III $17 \beta \mathrm{Hsd}$ abundantly (Ge \& Hardy 1998), 
while the expression of androgen metabolizing enzymes is downregulated, thereby leading to the highest net production of testosterone (Shan et al. 1993, Benton et al. 1995, Viger \& Robaire 1995). These stage-specific androgen profiles reflect the opposing actions of androgen biosynthetic and metabolizing enzymes (Shan et al. 1993, Ge \& Hardy 1998, Payne \& Hales 2004), and demarcate maturational transitions in LC development and differentiation (Shan et al. 1993, Ge et al. 1996, Wu et al. 2007).

Although the developmental progression of rat LC differentiation has been well characterized, these transitions have not been fully defined using primary LCs in mice. With the increasing use of genetically engineered mouse models, an accurate delineation of the normal developmental maturation of mouse LCs will facilitate the ability to recognize perturbations in LC development and function. Therefore, in this study, we have characterized and defined the transitional changes and hormonal profiles at sequential stages of postnatal LC development in mice.

\section{Results}

\section{Plasma hormone concentrations}

Plasma LH concentrations were low after birth until d14, and then started to increase at $\mathrm{d} 21-\mathrm{d} 28$ and became significantly higher at d35 (Fig. 1A). Mean LH increased further to a peak value at $\mathrm{d} 45$, and then remained elevated from this age onwards. After birth, plasma testosterone concentrations declined to a nadir at $\mathrm{d} 21$, and then started to increase at $\mathrm{d} 24$ and reached a significantly higher value at d35 (Fig. 1A). Plasma testosterone subsequently rose to peak concentrations at $\mathrm{d} 45$, and remained elevated thereafter.

\section{Intratesticular androgen concentrations}

Intratesticular concentrations of androstenedione, androstanediol, and testosterone were low from birth to d14 (Fig. 1B-D). At d24, intratesticular androstenedione first became significantly higher than that observed at younger ages and continued to rise through d45, and then remained elevated (Fig. 1B). Intratesticular androstanediol concentrations increased above the prepubertal range at $\mathrm{d} 21$, peaked at $\mathrm{d} 35$, and then declined to lower values from d45 to d180 (Fig. 1C). Intratesticular testosterone concentrations increased slightly at $d 7$, and then progressively increased to $d 45$ and remained elevated thereafter (Fig. 1D).

\section{In vitro basal androgen production}

Both basal and LH-stimulated in vitro production of androgens by cultured primary LCs were examined (Fig. 2). Basal androstenedione synthesis increased 10 -fold from d21 to d24 $(18.13 \pm 0.83$ vs 199.49 $\pm 2.99 \mathrm{pmol} / \mathrm{million}$ cells, $P<0.001)$ and progressively increased until $\mathrm{d} 45$, and then declined significantly from
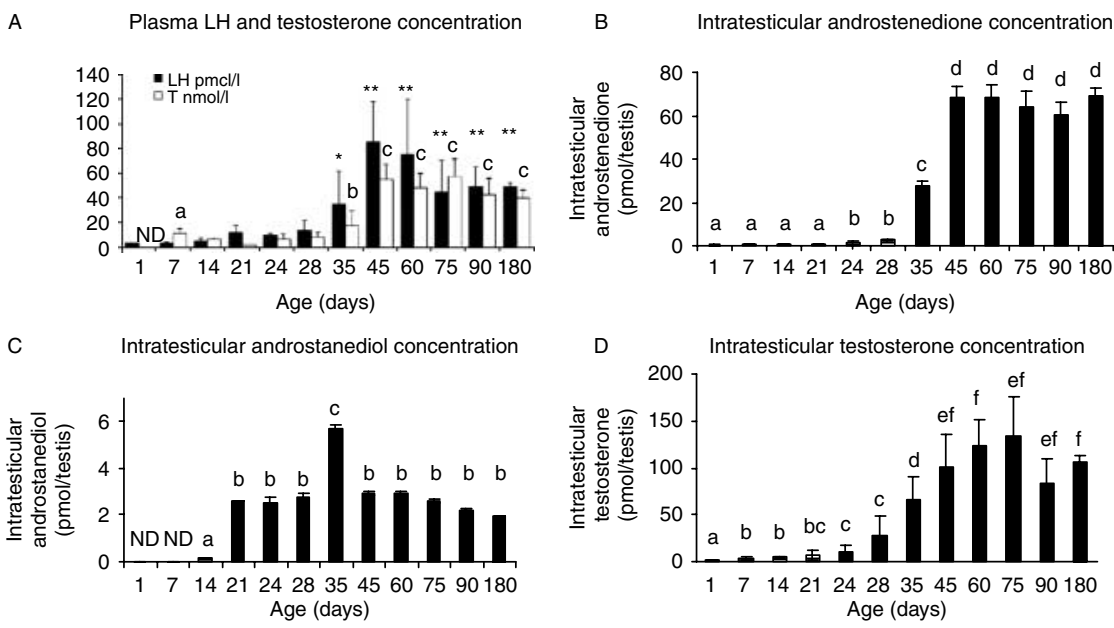

Figure 1 Plasma LH and testosterone concentrations. For mice younger than d14, plasma was pooled from three mice, and testicular extracts were pooled from 12 testes. At all other ages, individual plasma samples and testicular extracts were assayed. Each data point represents the mean $( \pm$ s.E.M.) of three sets of pooled samples or 3-9 individual samples run in duplicate. Different superscripts denote significant differences $(P<0.05)$. $\mathrm{ND}$, not done. (A) Plasma LH starts to rise at $\mathrm{d} 21$ and then increases progressively to $\mathrm{d} 45$, while plasma testosterone increases from $\mathrm{d} 24$ to $\mathrm{d} 45$, and is elevated through d180. *Plasma LH on d35 is significantly greater than that on $\mathrm{d} 1-\mathrm{d} 14$. ${ }^{* *}$ Plasma LH from d45 onwards is significantly greater than that observed at all other ages. (a) Plasma T on d7 is significantly greater than that on $\mathrm{d} 21$. (b) Plasma Ton d35 is significantly greater than that on $\mathrm{d} 21$. (c) Plasma T from d45 onwards is significantly greater than that observed at all other ages. (B) Intratesticular androstenedione initially increases above prepubertal values at $\mathrm{d} 24(P<0.05)$, and then rapidly rises until $\mathrm{d} 45$ and remains high through $\mathrm{d} 180$. (C) Intratesticular androstanediol increases at $\mathrm{d} 21$, and then remains unchanged except for a slight peak at $\mathrm{d} 35$. (D) Intratesticular testosterone progressively increases from d24 through $\mathrm{d} 45$, and then remains elevated. 

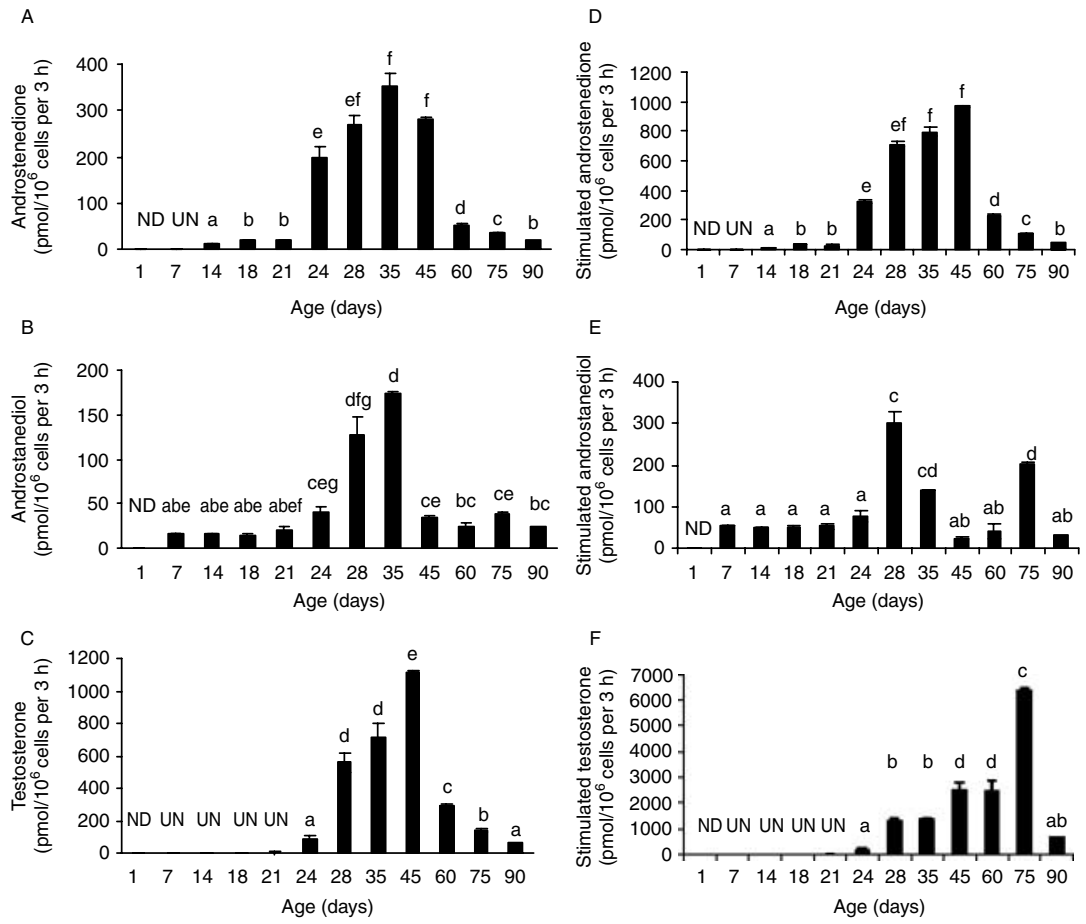

Figure 2 Basal $(\mathrm{A}-\mathrm{C})$ and $\mathrm{LH}$-stimulated (D-F) in vitro androgen production by primary Leydig cells. Primary LCs were cultured for $3 \mathrm{~h}$ with $0.07 \mathrm{nM}$ $(1 \mathrm{ng} / \mathrm{ml})$ and $7 \mathrm{nM}(100 \mathrm{ng} / \mathrm{ml}) \mathrm{LH}$. Conditioned media from primary LCs were assayed for androstenedione, androstanediol, and testosterone. Each data point (mean \pm s.E.M.) represents triplicate determinations of Leydig cells from 6 to 20 pooled testes. Different superscripts denote significant differences $(P<0.05)$. ND, not done. UN, undetectable values (below assay detection limits). Basal androgen production: (A) androstenedione in conditioned media increases above the prepubertal range at $\mathrm{d} 24$, rises steadily to a peak at $\mathrm{d} 45$, and then declines precipitously at $\mathrm{d} 60$.

(B) Androstanediolin in conditioned media dramatically increases from d24 to 35, and then declines to lower values by d45. (C) Testosterone in conditioned media first rises at $\mathrm{d} 24$, and then increases to peak at $\mathrm{d} 45$ with a rapid decline thereafter. $\mathrm{LH}$-stimulated androgen production:

(D) androstenedione increases at d24, reaches peak values at d35 and d45, and declines by d60. (E) Androstanediol is highest on d28, and then declines with another peak at $\mathrm{d} 75$. (F) Testosterone is first measurable at $\mathrm{d} 24$, and then progressively increases to a peak value at $\mathrm{d} 75 \mathrm{before}$ declining markedly at d90.

d60 onwards (Fig. 2A). The in vitro production of androstanediol was detected at $\mathrm{d} 7$ and was maximal at $\mathrm{d} 35$, and then declined to much lower levels from d45 to d90 (Fig. 2B). In vitro basal testosterone production was first measurable at $\mathrm{d} 24$, peaked at $\mathrm{d} 45$, and then decreased precipitously at $\mathrm{d} 60$ and continued to progressively decline thereafter (Fig. 2C).

In terms of basal androgen production, androstenedione was the predominant androgen produced at $\mathrm{d} 24$ $(199.49 \pm 2.99 \mathrm{pmol} / \mathrm{million}$ cells per $3 \mathrm{~h}$ compared with $40.07 \pm 4.17 \mathrm{pmol} / \mathrm{million}$ cells per $3 \mathrm{~h}$ for androstanediol and $86.13 \pm 7.75 \mathrm{pmol} / \mathrm{million}$ cells per $3 \mathrm{~h}$ for testosterone). In contrast, testosterone was the most abundant androgen produced at d45 (1117 $\pm 86.15 \mathrm{pmol} / \mathrm{million}$ cells per $3 \mathrm{~h}$ compared with $281.59 \pm 26.66 \mathrm{pmol} / \mathrm{million}$ cells per $3 \mathrm{~h}$ for androstenedione and $33.46 \pm 2.59 \mathrm{pmol} / \mathrm{million}$ cells per $3 \mathrm{~h}$ for androstanediol). Thus, the immature androgen, androstenedione, comprised $61 \%$ of the total androgens produced at $\mathrm{d} 24$, whereas a switch in the androgen production was noted by $\mathrm{d} 45$, when testosterone comprised $78 \%$ of the total androgen production.

\section{$L H$-stimulated in vitro androgen production}

The LH-stimulated androstenedione production by cultured primary LCs increased 11 -fold from d21 to d24 (from $28.45 \pm 0.48$ to $320.11 \pm 4.28 \mathrm{pmol} / \mathrm{million}$ cells per $3 \mathrm{~h}, P<0.001$ ) and continued to progressively increase until $\mathrm{d} 45$, and then declined from d60 onwards (Fig. 2D). The LH-stimulated production of androstanediol was detectable at $\mathrm{d} 7$, reached a maximum at $\mathrm{d} 28$, and then declined significantly by $\mathrm{d} 45$ with an isolated spike at d75 (Fig. 2E). LH-stimulated testosterone production was not detectable until $\mathrm{d} 24$, and then gradually increased to peak at $\mathrm{d} 75$, with a dramatic decrease at d90 (Fig. 2F).

With LH stimulation, androstenedione was the predominant biosynthetic androgen produced at $\mathrm{d} 24$ $(320.11 \pm 4.28 \mathrm{pmol} / \mathrm{million}$ cells per $3 \mathrm{~h}$ compared with $78.45 \pm 8.09 \mathrm{pmol} / \mathrm{million}$ cells per $3 \mathrm{~h}$ for androstanediol and $190.3 \pm 30.25 \mathrm{pmol} / \mathrm{million}$ cells per $3 \mathrm{~h}$ for testosterone). In contrast, testosterone was the most abundant androgen produced at $\mathrm{d} 45$ (2540 $\pm 38.27 \mathrm{pmol} / \mathrm{million}$ cells per $3 \mathrm{~h}$ compared with $967.32 \pm 30.97 \mathrm{pmol} / \mathrm{million}$ cells per $3 \mathrm{~h}$ for 
androstenedione and $23.87 \pm 1.71 \mathrm{pmol} / \mathrm{million}$ cells per $3 \mathrm{~h}$ for androstanediol). Consequently, at $\mathrm{d} 24$, androstenedione production comprised $54.4 \%$ of the total androgen production, whereas at $\mathrm{d} 45$, there was a shift to the predominant synthesis of testosterone, which comprised $71.9 \%$ of the total androgen production. The ability of $\mathrm{LH}$ to stimulate $\mathrm{LC}$ androgen production appeared to be acquired between $\mathrm{d} 21$ and $\mathrm{d} 24$. At $\mathrm{d} 21$, testosterone production did not rise in response to $\mathrm{LH}$ stimulation, whereas by $\mathrm{d} 24$, testosterone production increased 2.2-fold (from 86.13 \pm 7.75 to 190.3 $\pm 30.25 \mathrm{pmol} / \mathrm{million}$ cells per $3 \mathrm{~h}$ ).

\section{Steroidogenic enzyme expression}

The mRNA expression of androgen biosynthetic and metabolic enzymes was examined by northern blot analysis in total testicular RNA and by quantitative realtime PCR (QPCR) in RNAs extracted from purified mouse LCs. By northern blot analysis, P450scc and P450c17 $\alpha$ are detectable in total testis by $\mathrm{d} 7$ at low levels (most likely representing fetal LCs; Fig. $3 \mathrm{~A}$ and $\mathrm{B}$ ). Both RNAs are abundantly expressed from d24 to d60, and then decline in abundance thereafter. Using ImageJ software (http://rsb.info.nih.gov/ij), the mRNA bands for each time point were expressed as the ratio of $\mathrm{P} 450 \mathrm{scc} / \mathrm{S} 16$ and P450c17a/S16 (Fig. 3B).

By QPCR, the metabolic enzymes, $3 \alpha \mathrm{Hsd}$ and $5 \alpha$ reductase, were expressed most abundantly in mouse LCs at d21, and then decreased with subsequent maturation (Table 1). In contrast, the steroidogenic enzymes, $17 \beta \mathrm{Hsd}$ III, P450c17 $\alpha$, and StAR, were expressed at lower levels at $\mathrm{d} 21$ and $\mathrm{d} 24$, and then increased significantly at d35-d90 (Table 1). The mRNA expression of P450scc, by both northern blot analysis and QPCR, increased from d24 to $\mathrm{d} 60$, and then declined. The mRNA expression of $3 \beta \mathrm{Hsd}$ and $3 \beta \mathrm{Hsd}$ $\mathrm{VI}$ did not vary from $\mathrm{d} 24$ to $\mathrm{d} 60$ (data not shown). The mRNA expression of the LH receptor significantly rose from d14 (data not shown) to $\mathrm{d} 35$, and then remained abundantly expressed thereafter with minor fluctuations (Table 1).

To confirm that developmental changes in the mRNA expression of the steroidogenic enzymes at the key peripubertal transition from $\mathrm{d} 21$ to $\mathrm{d} 24$ were accompanied by parallel changes in protein expression, immunohistochemistry was performed on testicular sections. These studies showed an obvious increase in the number of LCs with positive staining for both P450scc and P450c17 $\alpha$ from d21 to d24 (Fig. 4A and B).

\section{Discussion}

The data demonstrate the developmental changes in murine LC differentiation and androgen production from birth through maturity. In comparison to published data obtained from rats, our data obtained from mice reveal
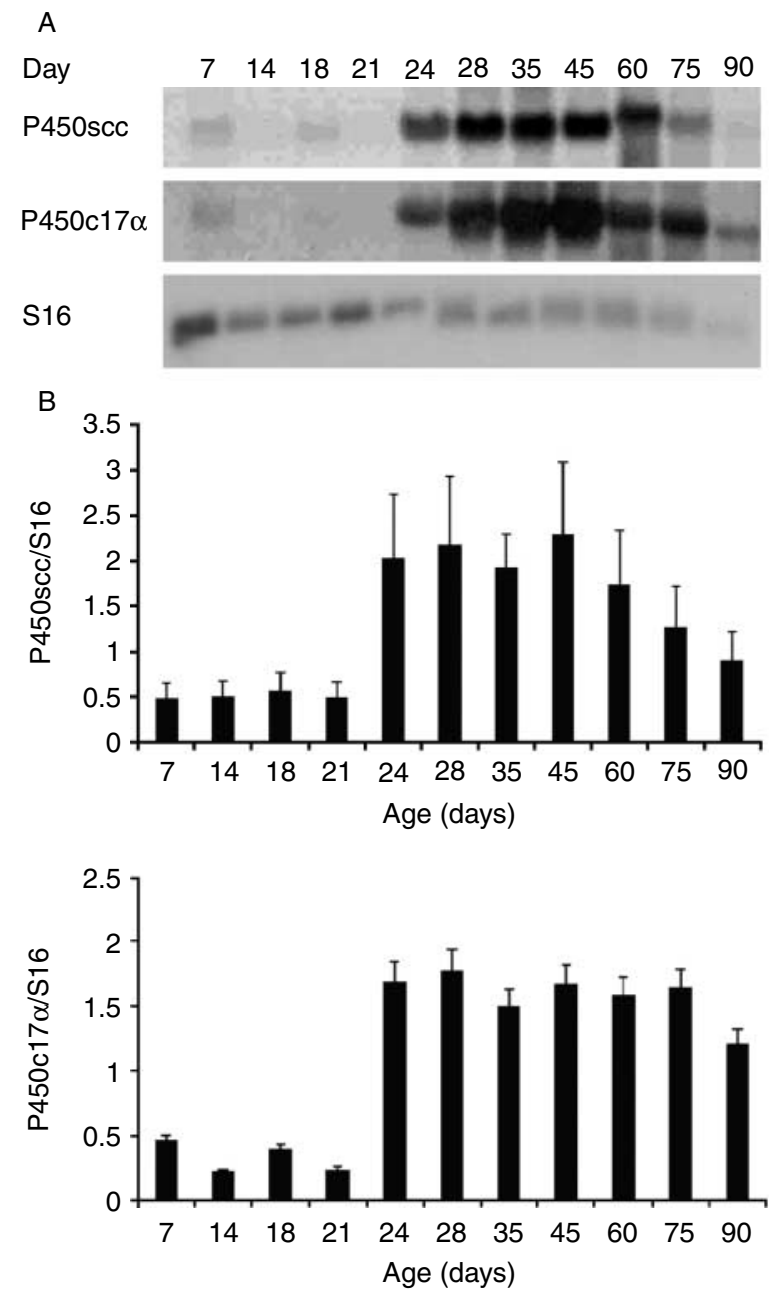

Figure 3 The mRNA expression of androgen biosynthetic and metabolic enzymes. (A) Total RNA was extracted from mouse testes collected from d7 to d90 for northern blot analysis. Ribosomal protein S16 was used as an internal control. P450scc and P450c17 $\alpha$ mRNAs are first detectable at $\mathrm{d} 24$, and are then abundantly expressed until d60. (B) The above northern blot was quantified using ImageJ software, and each time point was expressed as the ratio of P450scc/S16 and P450c17 $/$ /S16 (mean \pm S.E.M).

species differences in developmental androgen profiles and in the timing and pace of the maturational transition from an undifferentiated prepubertal LC to a sexually mature adult LC. This study demonstrates the differences between rats and mice in the response of LCs to LH stimulation and in the maturational profiles of steroidogenic and metabolic enzymes.

The general pattern of intratesticular androgen concentrations and steroidogenic enzyme mRNA expression across the pubertal transition is similar to that previously reported (Baker et al. 1997, 2003, O'Shaughnessy et al. 2002). In contrast to these studies, we examined steroidogenic enzyme expression in RNA isolated from purified LCs rather than that in RNA isolated from total testis or testicular webs, which includes a mixed population of cells (Baker et al. 
Table 1 The mRNA gene expression in primary Leydig cells from d21 to d90.

\begin{tabular}{|c|c|c|c|c|c|c|c|}
\hline Ages & Lhr & StAR & P450scc & P450c17 $\alpha$ & $17 \beta \mathrm{Hsd}$ III & $3 \alpha \mathrm{Hsd}$ & $5 \alpha$-reductase \\
\hline 21 & $0.67 \pm 0.03^{+, \neq}$ & $0.60 \pm 0.25^{*}$ & $4.12 \pm 0.27^{*,+}$ & $3.78 \pm 0.19 *$ & $0.01 \pm 0.001 *$ & $0.002 *$ & $0.36 \pm 0.018^{*}$ \\
\hline 24 & $0.57 \pm 0.03^{\neq, \S}$ & $0.45 \pm 0.14 *$ & $2.57 \pm 0.16^{*}$ & $3.07 \pm 0.59 *$ & $0.01 \pm 0.001 *$ & $0.03 \pm 0.007^{+}$ & $0.34 \pm 0.017^{*}$ \\
\hline 35 & $0.96 \pm 0.06 *$ & $1.26 \pm 0.45^{\dagger}$ & $7.55 \pm 0.14^{\neq, \S}$ & $8.15 \pm 0.58^{\dagger}$ & $0.12 \pm 0.011^{\dagger}$ & $0.03 \pm 0.001^{+}$ & $0.14 \pm 0.003^{+}$ \\
\hline 45 & $0.80 \pm 0.04^{*,+}$ & $1.47 \pm 0.59^{+}$ & $9.12 \pm 0.60^{\S}$ & $8.14 \pm 0.64^{+}$ & $0.15 \pm 0.005^{+, \neq}$ & $0.01 \pm 0.001^{\ddagger}$ & $0.18 \pm 0.005^{\dagger}$ \\
\hline 60 & $0.68 \pm 0.06^{+, \neq}$ & $1.52 \pm 0.48^{\dagger}$ & $11.47 \pm 0.77^{\S}$ & $10.25 \pm 0.30^{\dagger}$ & $0.26 \pm 0.026^{\S}$ & $0.02 \pm 0.001^{\S}$ & $0.04 \pm 0.009^{\ddagger}$ \\
\hline 90 & $0.38 \pm 0.06^{\S}$ & $1.29 \pm 0.45^{\dagger}$ & $5.91 \pm 0.13^{*, t, \neq}$ & $8.64 \pm 0.21^{\dagger}$ & $0.20 \pm 0.019^{\neq, \S}$ & $0.01 \pm 0.001^{\neq, \S}$ & $0.02 \pm 0.005^{\neq}$ \\
\hline
\end{tabular}

Each data point (mean \pm s.E.M.) represents the mean $m R N A$ expression normalized to actin from at least three separate Leydig cell isolations and RNA extractions. Different superscripts denote significant differences $(P<0.05)$.

1997, 2003, O'Shaughnessy et al. 2002). We also examined steroid production and $\mathrm{LH}$ responsiveness in highly purified primary LC preparations rather than that in non-purified interstitial or testicular fractions (Sheffield \& O'Shaughnessy 1988, O'Shaughnessy et al. 2002), which enabled us to quantify androgen production per given LC number and permitted more precise delineation of maturational changes in steroidogenesis. Studies using whole testicular extracts to examine enzymatic activity can reflect steroidogenic enzyme activity in Sertoli as well as LCs (Welsh \& Wiebe 1978, Sheffield \& O'Shaughnessy 1988). Moreover, the use of RNA from total testes or interstitial webs rather than that from LCs results in variability in the relative fraction of LC-specific RNA as the proportion of each cell type changes during pubertal maturation (Vergouwen et al. 1993). While overall changes in steroidogenic enzyme expression and androgen production exhibited similar profiles among the studies, discrete differences in amplitude or timing may reflect these methodological differences or perhaps strain differences.

The gradual rise in intratesticular concentrations of androstenedione and testosterone and the increasing responsiveness of isolated $\mathrm{LCs}$ to $\mathrm{LH}$ stimulation at the onset of puberty are comparable to previous reports in mice (O'Shaughnessy et al. 2000) and rats (Ge \& Hardy 1998, Mendis-Handagama et al. 1998). The predominant production of androstenedione at pubertal onset is due to the increased capacity of postnatal LCs to synthesize androgens as they differentiate from mesenchymal precursors and acquire expression of the steroidogenic enzymes. At this stage, the immature LCs abundantly express $5 \alpha$-reductase and $3 \alpha \mathrm{Hsd}$, but exhibit a much lower expression of $17 \beta \mathrm{Hsd}$ III, a pattern generally consistent with that reported previously (Shan et al. 1993, Baker et al. 1997, Ge \& Hardy 1998, O'Shaughnessy et al. 2002, Dong et al. 2007). Consequently, androstenedione and androstanediol rather than testosterone are produced preferentially by the immature peripubertal LCs. Androstenedione production by LCs continues to increase after d45 in rats, although constituting a smaller fraction of the total androgens produced (Ge \& Hardy 1998, Ariyaratne \& Chamindrani Mendis-Handagama 2000), while in mice, androstenedione synthesis by LCs declines dramatically
(Wu et al. 2005). Despite the decreased androstenedione production by isolated LCs, our data also confirm that intratesticular and plasma concentrations of androstenedione remain elevated in adult mice ( $\mathrm{O}^{\prime}$ 'Shaughnessy et al. 2000, Wu et al. 2005). This ability to maintain high concentrations of androstenedione despite a decreased in vitro capacity per LC for androstenedione synthesis could be explained by the presence of a higher percentage of immature LCs in the mouse testis than in the rat testis at these ages. In rats at comparable ages, there is minimal proliferation or differentiation of LCs as they have been shown to be terminally differentiated (Benton et al. 1995). Our preliminary data show a similar mitotic index in adult and prepubertal dividing mouse LCs by flow cytometry (X F Wu \& M M Lee, unpublished data). We hypothesize that continued recruitment of adult-type LCs from mesenchymal precursors is ongoing in the mouse testis, and that these newly maturing LCs make a substantial contribution to the type of androgens produced at these ages.

During pubertal development, a number of factors influence LC differentiation and steroidogenesis (Ge et al. 1996, Wu et al. 2007). Androstanediol reflects metabolic enzyme activity and is the major androgen produced by immature rat LCs (Benton et al. 1995, Ge \& Hardy 1998). Intratesticular concentrations of androstanediol peak in the pubertal mouse testis, and then decline with sexual maturation. In mice, in vitro production of $\mathrm{LH}$-stimulated androstanediol was maximal between $\mathrm{d} 28$ and $\mathrm{d} 35$, and then decreased at older ages (Sheffield \& O'Shaughnessy 1988, O'Shaughnessy et al. 2000) similar to that observed in rats (Benton et al. 1995, Killian et al. 2003). These developmental changes during testicular maturation in mice parallel the report in rats of increased activity of the metabolic enzymes during puberty followed by a subsequent decline in mature LCs (Shan et al. 1993). The similar patterns of androgen production and developmental changes in $3 \alpha \mathrm{HSD}$ and $5 \alpha$-reductase expression we observed in mice suggest that corresponding changes are at play during murine LC maturation. Therefore, the significant decline in androstanediol production and expression of $3 \alpha \mathrm{Hsd}$ from d 35 to d 45 may denote a maturational transition in the differentiation of the mouse LC towards a terminally differentiated mature state. 
A

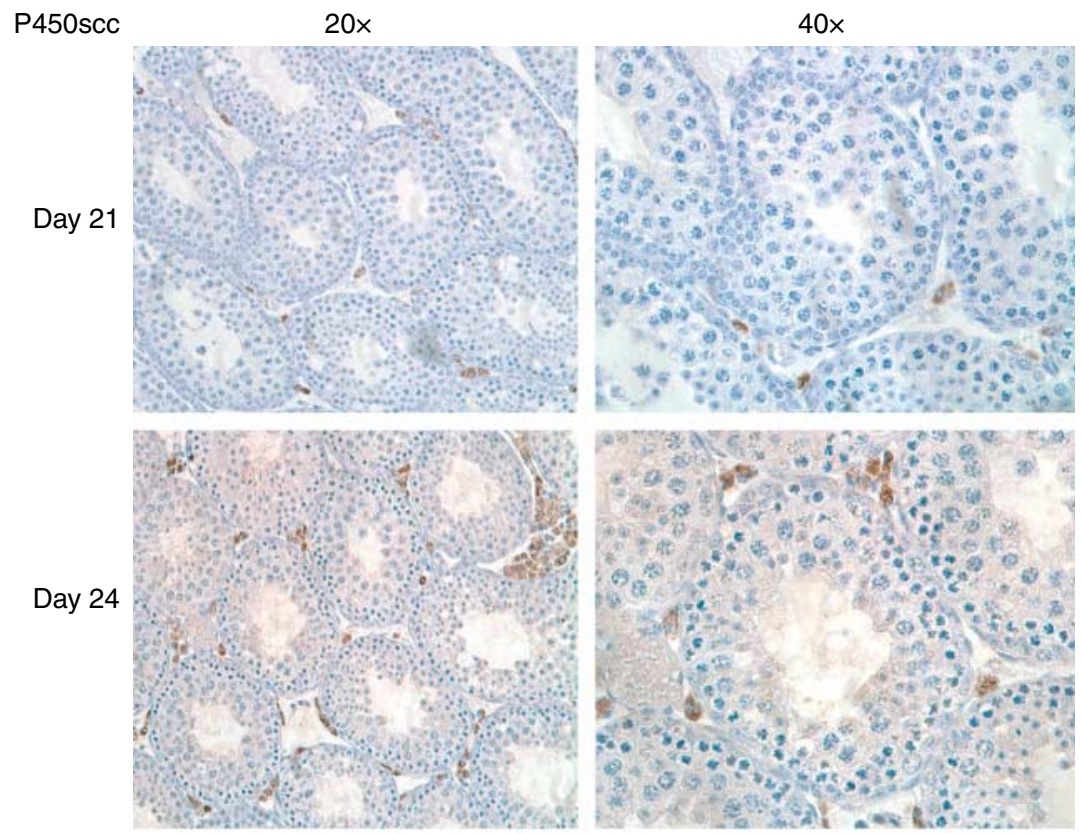

B

$P 450 c 17 \alpha$

$20 x$
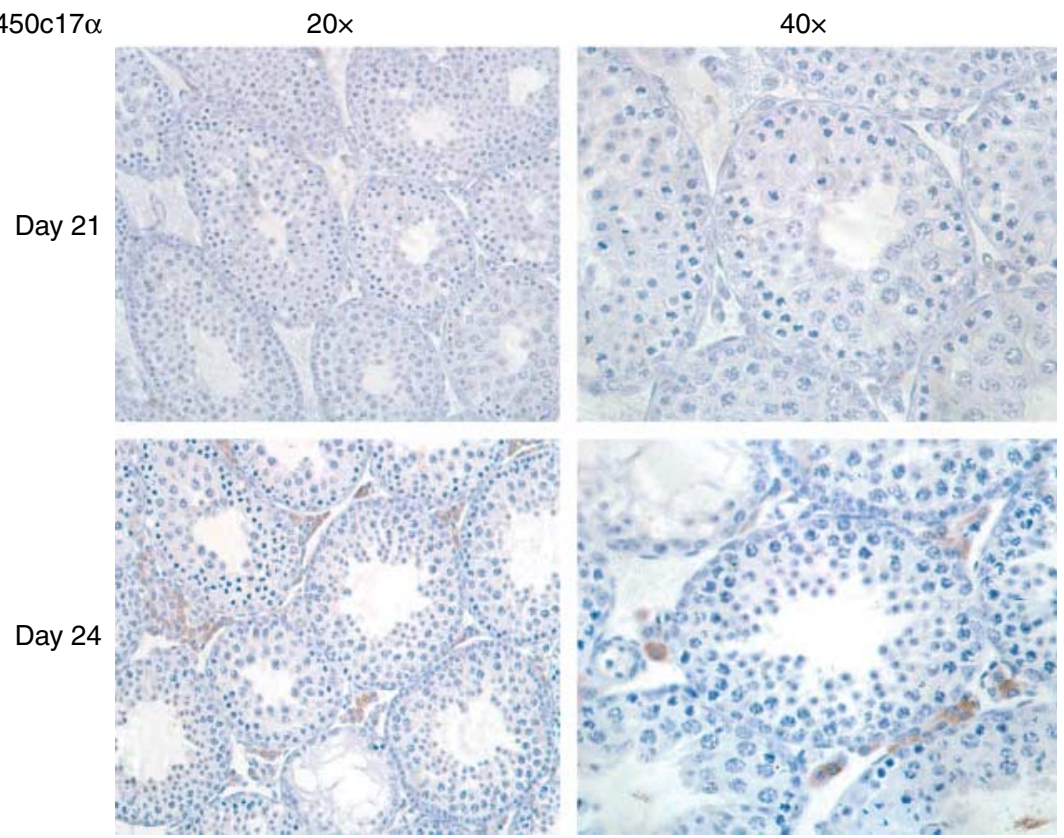

Figure 4 Immunohistochemistry of P450scc and P450c17 $\alpha$ expression in mouse testis. Staining for both P450scc (A) and P450c17 $\alpha$ (B) in testicular sections increases markedly from $\mathrm{d} 21$ to $\mathrm{d} 24$. Five-micrometre sections from three different mouse testes were examined.
Net testosterone production is dependent on both the balance of androgen metabolic and biosynthetic enzyme activity and the number of steroidogenically active LCs in the testes. In our mouse study, plasma and intratesticular testosterone concentrations, a steady-state measurement reflecting net actions of androgen biosynthetic and metabolizing enzymes, were high from d45 onwards, a pattern similar to that reported in mice (O'Shaughnessy et al. 2000, 2002, Wu et al. 2005) and rats (Ge \& Hardy 1998, Ariyaratne \& Chamindrani
Mendis-Handagama 2000). As rat LCs mature, a decrease in the expression of the enzymes that metabolize testosterone leads to increased net production of testosterone by ALCs (Ge \& Hardy 1998, Dong et al. 2007). Conversely, despite increasing concentrations of intratesticular testosterone, we found a decline in both basal and $\mathrm{LH}$-stimulated testosterone production by isolated LCs at $\mathrm{d} 60$ and $\mathrm{d} 90$ respectively. We speculate that this discrepancy, i.e. increased testicular testosterone concentrations in the adults versus 
decreased in vitro testosterone production, may reflect an increase in LC numbers that compensates for the decreased testosterone biosynthetic capacity per cell.

Our study has characterized androgen secretory profiles during murine reproductive development, and defined the biosynthetic capacity and LH responsiveness of maturing LCs. These data enabled us to clarify the maturational transitions when LCs become initially recognizable as progenitor cells, differentiate into immature LCs, and then terminally differentiate into adult LCs in mice. The initial evidence of puberty is a modest increment in androstanediol production that occurs at $\mathrm{d} 21$. The more characteristic features of puberty such as the onset of P450scc and P450c17 $\alpha$ expression and an increase in plasma and intratesticular concentrations of androstenedione and testosterone occur at $\mathrm{d} 24, \sim 3$ days later than that in rats (Benton et al. 1995, Ge et al. 1996). During this time period (from $\mathrm{d} 21$ to $\mathrm{d} 24$ ), the murine LCs become more responsive to $\mathrm{LH}$, as demonstrated by the rise in LH-stimulated testosterone production. In contrast, these maturational changes occur in rats at $\mathrm{d} 21$ (Benton et al. 1995). Our data suggest that the initial differentiation of mouse mesenchymal LCs to progenitor LCs may occur at d24 rather than at $\mathrm{d} 21$ as in rats.

The androstanediol data suggest that murine progenitor LCs differentiate into immature LCs by d35, similar to the timing reported in rats (Benton et al. 1995). The pubertal decline in androstanediol production and $3 \alpha \mathrm{Hsd}$ expression and corresponding rise in testosterone at $\mathrm{d} 45$ are hallmarks of terminal LC differentiation, and indicate that maturation of the LCs from an immature to adult stage occurs at d45 in mice. In contrast, these changes are observed at d56 in rats (Benton et al. 1995). Thus, the maturational progression from progenitor to adult LCs in CD1 mice occurs in a compressed developmental window as compared with rats.

In conclusion, our data show that the postnatal development of mouse and rat LCs differs in its onset and pace of progression. Therefore, data on rat LC maturation must be applied with caution to studies in mice. This study complements existing normative data on the patterns of androgen biosynthesis and differentiation in mice to facilitate the assessment of reproductive phenotypes of recombinant mouse models.

\section{Materials and Methods}

\section{Animals}

CD1 mice were purchased from Charles River Laboratories (Wilmington, MA, USA and Raleigh, NC, USA). Blood and testes were collected after killing by carbon dioxide asphyxiation at 1, 7, 14, 18, 21, 24, 28, 35, 45, 60, 75, 90, and 180 days. The day of birth was designated as d1. All experimental protocols were approved by the Institutional Animal Care and Use Committees of the University of
Massachusetts Medical School (A1619), and Duke University Medical Center (A 433-00-09).

To prepare testicular extracts, the testes were homogenized in $900 \mu \mathrm{l}$ TBSG buffer $(0.1 \%$ gelatin $(\mathrm{w} / \mathrm{v}), 28 \mathrm{mM}$ Trizma $\mathrm{HCl}$, $22 \mathrm{mM}$ Trizma base, $100 \mathrm{mM} \mathrm{NaCl}$, and $15 \mathrm{mM} \mathrm{NaN}_{3}$ ). After pelleting cellular debris, the supernatants were collected for hormone analysis.

\section{Isolation of primary LCs}

Testes were harvested, decapsulated, dispersed with collagenase $(0.05 \%(\mathrm{w} / \mathrm{v})$, and fractionated in Percoll gradient as described for rat LC isolation (Klinefelter et al. 1987, 1993) with minor modifications (Salva et al. 2001). The fractionated LCs were purified through a $2.5-10 \%$ gradient of BSA (Sigma) to remove contaminating sperm (Salva et al. 2001). The purity of each LC preparation, assessed by $3 \beta \mathrm{HSD}$ staining with $0.4 \mathrm{mM}$ etiocholanolone, was $>90 \%$ (Payne et al. 1980).

\section{In vitro cell culture}

Freshly harvested LCs were cultured at $2.5 \times 10^{4}$ cells $/ \mathrm{ml}$ in serum-free media (phenol red-free DMEM/F12) supplemented with $15 \mathrm{mM}$ HEPES, $26 \mathrm{mM}$ sodium bicarbonate, $0.1 \%$ BSA $(\mathrm{w} / \mathrm{v}), 0.0012 \%$ gentamicin $(\mathrm{w} / \mathrm{v})$, and either $0.07 \mathrm{nM}(1 \mathrm{ng} / \mathrm{ml})$ or $7 \mathrm{nM}(100 \mathrm{ng} / \mathrm{ml}) \mathrm{LH}$. After gentle rotatory agitation for $3 \mathrm{~h}$ in a $34{ }^{\circ} \mathrm{C}$ water bath at 105 r.p.m. (for PLCs and ILCs) or 85 r.p.m. (for ALCs), the cells were pelleted by centrifugation at $16000 \mathrm{~g}$ for $8 \mathrm{~min}$. Conditioned media were collected and stored at $-20{ }^{\circ} \mathrm{C}$ until hormone assays.

\section{Hormone assays}

Testosterone, androstenedione, and androstanediol were measured by RIA in plasma, in conditioned medium from in vitro LC cultures, and in supernatants of total testicular homogenates (Coffey et al. 1971, Cochran et al. 1979, 1981). All samples were assayed in duplicate, and each experimental data point consisted of 3-6 samples. The androstenedione rabbit antiserum (Sigma) is $100 \%$ specific for androstenedione (Weinstein et al. 1972). Testosterone antibody was obtained from Dr Gordon Niswender (Cochran et al. 1981), and androstanediol rabbit antiserum was obtained from Dr Gerald Barbe, University of Western Ontario, London, Canada (Zamecnik et al. 1977). Both antibodies are highly specific and have minimal cross-reactivity with other commercial steroids. The lower limit of detection for the androgen assays was $114 \mathrm{pM}(33 \mathrm{pg} / \mathrm{ml})$. Intra- and inter-assay coefficients of variation (CV) were 9.04 and $7.76 \%$ respectively for testosterone; 6.1 and $5.76 \%$ for androstenedione; and 6.98 and $3.97 \%$ for androstanediol. LH was assayed by mouse sandwich IRMA at the University of Virginia (UVa) Center for Research in Reproduction Ligand Assay and Analysis Core (NICHD, U54HD28934). The sensitivity of the $\mathrm{LH}$ assay is $5 \times 10^{-3} \mathrm{nM}$ $(0.07 \mathrm{ng} / \mathrm{ml})$. The intra-assay $\mathrm{CV}$ of $6.0 \%$ for the $\mathrm{LH}$ assay was determined by taking the average of $\mathrm{CV}$ for all controls (in the low, medium, and high range) in that particular assay. 
Table 2 Primer sequences for real-time PCR.

\begin{tabular}{|c|c|c|}
\hline Gene name & Sense & Antisense \\
\hline$L H R$ & 5'-TAACCACCATACCAGGGAACGCTT-3' & 5'-TAACTCCAGCGAGATTAGCGTCGT-3' \\
\hline StAR & 5'-ACAACCAGGAAGGCTGGAAG-3' & $5^{\prime}$-ATGCAGGTGGGGCCGTGTTCA-3' \\
\hline $3 \beta H S D I$ & 5'-CTCAGTTCTTAGGCTTCAGCAATTAC-3' & 5'-CCAAAGGCAAGATATGATTTAGGA-3' \\
\hline $5 \alpha$-reductase type I & $5^{\prime}$-TCACCTTTGTCTTGGCCTTCCTGT-3' & $5^{\prime}$-GTTTCCCCTGGTTTTCTCAGATTC-3' \\
\hline $3 \alpha H S D$ & $5^{\prime}$-GGAAAACTGTTGGCTGAAGCA-3' & $5^{\prime}$-CCAGTCCGGCATCTTTACACTT-3' \\
\hline $17 \beta H S D I I I$ & 5'-ATTTTACCAGAGAAGACATCT-3' ${ }^{\prime}$ & 5'-GGGGTCAGCACCTGAATAATG-3' \\
\hline $3 \beta H S D V I$ & 5'-AAGССТСТСАGСАССТСТTG-3' & $5^{\prime}$-TGTTTCTTCCATTGGGTTTCA-3' \\
\hline Actin & 5'-ACTTGCGCTCAGGAGGAGCAATG-3' & 5'-ACAGCTGAGAGGGAAATCGTGCG-3' \\
\hline
\end{tabular}

The inter-assay CV of $12.5 \%$ was the mean overall CV for the LH assay in the calendar year of the assay, derived by calculating the mean of all CV for the low, medium, and high-range controls.

\section{Northern blot analysis}

To assess androgen biosynthetic capacity, the expression of P450scc and P450c17 $\alpha$ was examined by northern blot analysis. Total testicular RNAs were isolated using TRIzol (Invitrogen). Ten micrograms of RNA were loaded in each lane and electrophoresed in a $1.0 \%$ denaturing agarose gel in MOPS, blotted onto nylon membranes (NEN Life Science Products Inc., Boston, MA, USA), and hybridized overnight at $68^{\circ} \mathrm{C}$ with $1 \times 10^{6} \mathrm{cpm} / \mathrm{ml}$ of P450scc- or P450c17 $\alpha$ P32labeled probes. The membranes were reprobed with a S16 housekeeping gene probe at $42{ }^{\circ} \mathrm{C}$ to normalize the target signal. At each age, northern blot analyses were performed with three different RNA isolates from whole testes. Band intensities were quantified by ImageJ Software, normalized to S16, and results were expressed as mean \pm S.E.M.

\section{Quantitative RT-PCR}

RNA was extracted from freshly isolated LCs using TRIzol (Invitrogen), and was then treated with DNase and used for cDNA synthesis using the High Capacity cDNA RT kit (Applied Biosystem, Foster, CA, USA). cDNA was used for QPCR amplification using the Mastercycler Realplex2 (Eppendorf, Westbury, NY, USA). For all experiments, murine $\beta$-actin was amplified as an internal quality control. The QPCR was carried out in $20 \mu \mathrm{l}$ volume using the QuantiTect SYBR Green PCR kit (Qiagen). Each reaction mixture contained $1 \times$ reaction buffer, $2.5 \mathrm{mM} \mathrm{MgCl} 2,200 \mu \mathrm{M}$ dNTPs, $150-400 \mathrm{nM}$ of the specific primer, and HotStarTaq DNA polymerase. After incubation at $95{ }^{\circ} \mathrm{C}$ for $15 \mathrm{~min}$ and 45 cycles of $95^{\circ} \mathrm{C}$ for $20-30 \mathrm{~s}, 52-56{ }^{\circ} \mathrm{C}$ for $20-30 \mathrm{~s}$, and $72{ }^{\circ} \mathrm{C}$ for $20-45 \mathrm{~s}$, the relative amount of the initial mRNA copies was determined by calculating the difference $\left(\Delta C_{\mathrm{t}}\right)$ in threshold cycle $\left(C_{\mathrm{t}}\right)$ value between the target gene and actin, which was then interpreted as $2-\Delta C_{\mathrm{t}}$ to represent the target gene concentration. $\beta$-Actin was selected as the housekeeping gene after screening of several housekeeping genes and finding that $\beta$-actin expression did not vary significantly from $\mathrm{d} 21$ onwards in isolated LCs (O'Shaughnessy et al. 2002). The reaction efficiency of each gene was calculated according to $E=10^{(-1 / \text { slope })}$, and it ranged from 1.95 to 2.10 (Rasmussen 2001). The mRNA expression of each transcript was calculated as the ratio of the target gene to $\beta$-actin using $2^{-\left(\operatorname{target} C_{\mathrm{t}} \text {-actin } C_{\mathrm{t}}\right)}$, which is comparable with the Livak method (Livak \& Schmittgen 2001). The real-time PCR analysis was repeated at least three times for each gene with different pools of primary LCs. The data represent the mean \pm s.E.M. of at least three RT-PCR analyses. All primers except $3 \beta \mathrm{HSD} \mathrm{VI}$ were designed to produce an amplicon spanning at least one intron-exon boundary (see Table 2 for primer sequences).

\section{Immunohistochemistry}

Testes from a minimum of three mice at $\mathrm{d} 21$ and $\mathrm{d} 24$ were fixed in Bouin's fixative overnight, and then embedded in paraffin for cutting of $5-\mu \mathrm{m}$ sections. For immunohistochemistry, the sections were blocked for $1 \mathrm{~h}$ in $1.5 \%$ normal goat serum, and then incubated overnight at $4{ }^{\circ} \mathrm{C}$ with the primary antibody at a concentration of 1:2000 for both anti-P450c17 (Dr Dale Buchanan Hales, University of Illinois, Chicago, IL, USA) and anti-P450scc (Research Diagnostics, Flanders, NJ, USA). The sections were incubated with biotinylated anti-rabbit IgG secondary antibody and then with the avidin-biotin immunoperoxidase system (Vectastain ABC kit, Vector Laboratories, Inc., Burlinggame, CA, USA) and 3,3'-diaminobenzidine tetrachloride (Boehringer Mannheim). The sections were counterstained with hematoxylin. Alternate sections were processed with PBS instead of the primary antibody for a negative primary antibody control. P450scc and P450c17 staining of sections from $\mathrm{d} 21$ and $\mathrm{d} 24$ mice were compared by counting 500 cells in random sections.

\section{Statistical analysis}

All computations and data analyses were performed using the mixed model of ANOVA in SAS (SAS 1997). Androgen and $\mathrm{LH}$ concentrations below the lower limits of the assays were considered undetectable, and were assigned values of $7 \times 10^{-4} \mathrm{nM}(0.01 \mathrm{ng} / \mathrm{ml})$ for statistical analysis. Differences were regarded as significant if $P<0.05$.

\section{Declaration of interest}

The authors declare that there is no conflict of interest that could be perceived as prejudicing the impartiality of the research reported.

\section{Funding}

This work was supported by grants given to $M M$ Lee by the National Institute of Child Health and Human Development (NICHD) (K02-HD01367, R29-HD36768, R01-HD045773). 
LH was assayed at the Ligand Assay and Analysis Core of the UVa Center for Research in Reproduction (NICHD (SCCPRR) U54-HD28934). Core resources supported by the Diabetes Endocrinology Research Center grant DK32520 from the NIDDK were used.

\section{Acknowledgements}

This work is dedicated to the late Dr Matthew P Hardy of the Population Council who generously shared his insights and technical expertise with us at the start of this study.

\section{References}

Ariyaratne HB \& Chamindrani Mendis-Handagama S 2000 Changes in the testis interstitium of Sprague-Dawley rats from birth to sexual maturity. Biology of Reproduction 62 680-690.

Baker PJ, Sha JH \& O'Shaughnessy PJ 1997 Localisation and regulation of $17 \beta$-hydroxysteroid dehydrogenase type 3 mRNA during development in the mouse testis. Molecular and Cellular Endocrinology 133 127-133.

Baker PJ, Pakarinen P, Huhtaniemi IT, Abel MH, Charlton HM, Kumar TR \& O'Shaughnessy PJ 2003 Failure of normal Leydig cell development in follicle-stimulating hormone (FSH) receptor-deficient mice, but not FSH $\beta$-deficient mice: role for constitutive FSH receptor activity. Endocrinology 144 138-145.

Benton L, Shan LX \& Hardy MP 1995 Differentiation of adult Leydig cells. Journal of Steroid Biochemistry and Molecular Biology 53 61-68.

Cochran RC, Schuetz AW \& Ewing LL 1979 Age-related changes in conversion of $5 \alpha$-androstan- $17 \beta$-ol-3-one to $5 \alpha$-androstane- $3 \alpha, 17 \beta$-diol and $5 \alpha$-androstane-3 $\beta, 17 \beta$-diol by rat testicular cells in vitro. Journal of Reproduction and Fertility 57 143-147.

Cochran R, Ewing L \& Niswender G 1981 Serum levels of follicle stimulating hormone, luteinizing hormone, prolactin, testosterone, $5 \alpha$ dihydrotestosterone, $5 \alpha$-androstane- $3 \alpha, 17 \beta$-diol, $5 \alpha$-androstane- $3 \beta$ $17 \beta$-diol, and $17 \beta$-estradiol from male beagles with spontaneous or induced benign prostatic hyperplasia. Investigative Urology 19 142-147.

Coffey JC, French FS \& Nayfeh SN 1971 Metabolism of progesterone by rat testicular homogenates. IV. Further studies of testosterone formation in immature testis in vitro. Endocrinology 89 865-872.

Dong L, Jelinsky SA, Finger JN, Johnston DS, Kopf GS, Sottas CM, Hardy MP \& Ge RS 2007 Gene expression during development of fetal and adult Leydig cells. Annals of the New York Academy of Sciences 1120 16-35.

Ge R \& Hardy MP 1998 Variation in the end products of androgen biosynthesis and metabolism during postnatal differentiation of rat Leydig cells. Endocrinology 139 3787-3795.

Ge RS, Shan LX \& Hardy MP 1996 Pubertal development of Leydig cells. In The Ledig Cell, edn 1, pp 159-174. Eds AH Payne, MP Hardy \& LD Russell. Vienna: Cache River Press.

Gondos B, Morrison KP \& Renston RH 1977 Leydig cell differentiation in the prepubertal rabbit testis. Biology of Reproduction 17 745-748.

Hardy MP, Zirkin BR \& Ewing LL 1989 Kinetic studies on the development of the adult population of Leydig cells in testes of the pubertal rat. Endocrinology 124 762-770.

Kerr JB \& Knell CM 1988 The fate of fetal Leydig cells during the development of the fetal and postnatal rat testis. Development 103 535-544.

Killian J, Pratis K, Clifton RJ, Stanton PG, Robertson DM \& O'Donnell L $20035 \alpha$-reductase isoenzymes 1 and 2 in the rat testis during postnatal development. Biology of Reproduction 68 1711-1718.

Klinefelter GR, Hall PF \& Ewing LL 1987 Effect of luteinizing hormone deprivation in situ on steroidogenesis of rat Leydig cells purified by a multistep procedure. Biology of Reproduction 36 769-783.

Klinefelter GR, Kelce WR \& Hardy MP 1993 Isolation and culture of Leydig cells from adult rats. In Methods in Reproductive Toxicology, pp 166-181. Eds J Heindel \& RE Chaplin. San Diego, CA, USA: Academic Press.

Kuopio T, Paranko J \& Pelliniemi LJ 1989 Basement membrane and epithelial features of fetal-type Leydig cells in rat and human testis. Differentiation 40 198-206.
Livak KJ \& Schmittgen TD 2001 Analysis of relative gene expression data using real-time quantitative PCR and the $2(-$ Delta Delta $C(\mathrm{~T}))$ method. Methods 25 402-408.

Mendis-Handagama SM, Risbridger GP \& de Kretser DM 1987 Morphometric analysis of the components of the neonatal and the adult rat testis interstitium. International Journal of Andrology 10 525-534.

Mendis-Handagama SM, Ariyaratne HB, Teunissen van Manen KR \& Haupt RL 1998 Differentiation of adult Leydig cells in the neonatal rat testis is arrested by hypothyroidism. Biology of Reproduction 59 351-357.

Nef S, Shipman T \& Parada LF 2000 A molecular basis for estrogen-induced cryptorchidism. Developmental Biology 224 354-361.

O'Shaughnessy PJ, Baker PJ, Heikkila M, Vainio S \& McMahon AP 2000 Localization of $17 \beta$-hydroxysteroid dehydrogenase/17-ketosteroid reductase isoform expression in the developing mouse testis androstenedione is the major androgen secreted by fetal/neonatal leydig cells. Endocrinology 141 2631-2637.

O'Shaughnessy PJ, Willerton L \& Baker PJ 2002 Changes in Leydig cell gene expression during development in the mouse. Biology of Reproduction 66 966-975.

Payne AH \& Hales DB 2004 Overview of steroidogenic enzymes in the pathway from cholesterol to active steroid hormones. Endocrine Reviews 25 947-970.

Payne AH, Downing JR \& Wong KL 1980 Luteinizing hormone receptors and testosterone synthesis in two distinct populations of Leydig cells. Endocrinology 106 1424-1429.

Rasmussen R 2001 Quantification on the LightCycler. In Rapid Cycle RealTime PCR, Methods and Applications, pp 21-34. Eds S Meuer, C Wittwer \& K Nakagawara. Heidelberg: Springer Press.

Salva A, Klinefelter GR \& Hardy MP 2001 Purification of rat leydig cells: increased yields after unit-gravity sedimentation of collagenasedispersed interstitial cells. Journal of Andrology 22 665-671.

Shan LX, Phillips DM, Bardin CW \& Hardy MP 1993 Differential regulation of steroidogenic enzymes during differentiation optimizes testosterone production by adult rat Leydig cells. Endocrinology 133 2277-2283.

Sheffield JW \& O'Shaughnessy PJ 1988 Testicular steroid metabolism during development in the normal and hypogonadal mouse. Journal of Endocrinology 119 257-264.

Vergouwen RP, Jacobs SG, Huiskamp R, Davids JA \& de Rooij DG 1991 Proliferative activity of gonocytes, Sertoli cells and interstitial cells during testicular development in mice. Journal of Reproduction and Fertility $\mathbf{9 3}$ 233-243.

Vergouwen RP, Huiskamp R, Bas RJ, Roepers-Gajadien HL, Davids JA \& de Rooij DG 1993 Postnatal development of testicular cell populations in mice. Journal of Reproduction and Fertility 99 479-485.

Viger RS \& Robaire B 1995 Steady state steroid $5 \boldsymbol{\alpha}$-reductase messenger ribonucleic acid levels and immunocytochemical localization of the type 1 protein in the rat testis during postnatal development. Endocrinology 136 5409-5415.

Weinstein A, Lindner HR, Friedlander A \& Bauminger S 1972 Antigenic complexes of steroid hormones formed by coupling to protein through position 7: preparation from 4-3-oxosteroids and characterization of antibodies to testosterone and androstenedione. Steroids 20 789-812.

Welsh MJ \& Wiebe JP 1978 Sertoli cell capacity to metabolize C19 steroids: variation with age and the effect of follicle-stimulating hormone. Endocrinology 103 838-844.

Wu X, Arumugam R, Baker SP \& Lee MM 2005 Pubertal and adult Leydig cell function in Mullerian inhibiting substance-deficient mice. Endocrinology 146 589-595.

Wu X, Wan S \& Lee MM 2007 Key factors in the regulation of fetal and postnatal Leydig cell development. Journal of Cellular Physiology 213 429-433.

Zamecnik J, Barbe G, Moger WH \& Armstrong DT 1977 Radioimmunoassays for androsterone, $5 \alpha$-androstane- $3 \alpha, 17 \beta$-diol and $5 \alpha$-androstane$3 \beta, 17 \beta$-diol. Steroids 30 679-689.

Received 13 August 2009

First decision 11 September 2009

Revised manuscript received 23 April 2010

Accepted 6 May 2010 